\title{
Study on the Antimicrobial Effects of Novel Thiazole Derivatives
}

\author{
Meral Yılmaz Cankılıç, Leyla Yurttaş
}

\begin{abstract}
In this work, six 2-[(1/4-methylimidazol/triazol/tetrazol2/3/5-yl)thio]-N-(4-substituted thiazol-2-yl) acetamide derivatives (2a-f) were synthesized. The antimicrobial activities of these substances were examined against some foodborne Gram positive and Gram negative test bacteria, Candida albicans,
\end{abstract}

Candida glabrata, Candida krusei, and Candida parapsilosis yeasts, and some Aspergillus and Penicillium filamentous fungi species. The substances were shown considerable antimicrobial effect to tested pathogenic microorganisms.

Keywords: antibacterial, antifungungal, thiazole
Meral Yılmaz Cankılıç

Department of Biology, Faculty of Sciences, Anadolu University, 26470, Eskişehir, TURKEY

Leyla Yurttaş

Department of Pharmaceutical Chemistry, Faculty of Pharmacy, Anadolu University, 26470, Eskişehir, TURKEY

Corresponding Author:

Meral Yılmaz Cankilıç

e-mail:meralyilmaz@anadolu.edu.tr

Submitted / Gönderilme: 23.01.2017

Accepted / Kabul: 07.03.2017

\section{INTRODUCTION}

Infectious diseases are one of the most important clinical problems in the worldwide. If microorganisms develop resistance to drugs that are used continuously, many diseases become difficult to control. Thanks to the progress in biosynthesis, it is possible to create libraries of molecules and some of them may have minor modifications that present special value if the molecule is to work as a drug. These new molecules may start to produce a different set of possibly valuable products that have biological activity. One of these molecules, thiazole is a five-membered heterocyclic ring which is important fragment of naturally existing molecules thiamine (vitamin B1), thiamine pyrophosphate (TPP, a coenzyme important in respiration in the Krebs cycle), epothilones, carboxylase, and the large family of macrocyclic thiopeptide antibiotics, thiostrepton and micrococcin P1. Because of its biological importance and easibility of ring synthesis, thiazole containing compounds have been widely studied (1-3). Their derivatives combined with various heterocyclics have been reported with a broad spectrum of biological and pharmacological activities such as anaesthetic (4, 5), antitubercular (6), antibacterial, antifungal (7-9), analgesic (10) anticancer (11) activity, and inhibition of acetylcholinesterase activity (12). Therefore much interest has been focused on biological activity of thiazole derivatives. 
The purpose of this study was to synthesize of 2-[(1/4-methylimidazol/triazol/tetrazol-2/3/5-yl)thio]$N$-(4-substituted thiazol-2-yl)acetamide derivatives (2af) by appropriate methods and screening for antimicrobial activity for some foodborne pathogenic bacteria, yeasts and filamentous fungi.

\section{MATERIALS AND METHODS}

\section{Materials}

\section{General}

All chemicals were purchased from Sigma-Aldrich Chemical Co (Sigma-Aldrich Corp., St. Louis, MO, USA) and Merck Chemicals (Merck KGaA, Darmstadt, Germany). All melting points (m.p.) were determined by MP90 digital melting point apparatus (Mettler Toledo, Ohio, USA) and were uncorrected. All reactions were monitored by thin-layer chromatography (TLC) using Silica Gel 60 F254 TLC plates (Merck KGaA, Darmstadt, Germany). Spectroscopic data were recorded with the following instruments: IR, Shimadzu Affinity 1S spectrophotometer (Shimadzu, Tokyo, Japan); NMR, Agilent $300 \mathrm{MHz}$ NMR spectrometer (Agilent technologies, California, USA), in DMSO- $d_{6}$, using TMS as internal standard; $\mathrm{M}+1$ peaks were determined by Shimadzu 8040 LC/MS/MS system (Shimadzu, Tokyo, Japan). Elemental analyses were performed on a Leco 932 CHNS analyzer (Leco, Michigan, USA).

General procedure for the synthesis of 2-[(1/4-methylimidazol/triazol/tetrazol-2/3/5-yl)thio]-N(4-substituted thiazol-2-yl)acetamide derivatives (2a-f)

A mixture of 2-chloro-(4-substituted thiazol-2-yl)acetamide (1a, 1b) (2 mmol) and the appropriate thiol derivative (2 $\mathrm{mmol}$ ) and $\mathrm{K}_{2} \mathrm{CO}_{3}(2.4 \mathrm{~mol})$ were stirred in $40 \mathrm{ml}$ of acetone at room temperature for $5 \mathrm{~h}$. Acetone was evaporated until dryness. The residue was washed with water and recrystallized from ethanol to obtain compounds $2 \mathbf{a}-\mathbf{f}$ (13).

\section{2-[(1-Methyl-1H-imidazol-2-yl)thio]-N-(thiazol-2-yl) acetamide $(2 a)$}

Yield: 75 \%. M.p. $159^{\circ} \mathrm{C}$.

${ }^{1} \mathrm{H}-\mathrm{NMR}\left(300 \mathrm{MHz}, \mathrm{DMSO}-\mathrm{d}_{6}, \mathrm{ppm}\right) \delta: 3.59\left(3 \mathrm{H}, \mathrm{s},-\mathrm{CH}_{3}\right)$, $3.97\left(2 \mathrm{H}, \mathrm{s},-\mathrm{CH}_{2}\right), 6.94(1 \mathrm{H}, \mathrm{s}, \mathrm{Ar}-\mathrm{H}), 7.22(1 \mathrm{H}, \mathrm{d}, J=3.54$ $\mathrm{Hz}, \mathrm{Ar}-\mathrm{H}), 7.25$ (1H, s, Ar-H), 7.46 (1H, d, J=3.54 Hz, Ar-H), 12.47 (1H, s, -NH).
${ }^{13} \mathrm{C}-\mathrm{NMR}$ (75 MHz, DMSO-d , ppm) $\delta: 33.44,37.32,114.17$, $124.12,129.05,138.20,139.70,158.23,167.30$.

For $\mathrm{C}_{9} \mathrm{H}_{10} \mathrm{~N}_{4} \mathrm{OS}_{2}$ calculated: $42.50 \% \mathrm{C}, 3.96 \% \mathrm{H}, 22.03 \% \mathrm{~N}$, found: $42.54 \% \mathrm{C}, 3.89 \% \mathrm{H}, 22.08 \% \mathrm{~N}$.

HRMS (m/z): $[\mathrm{M}+\mathrm{H}]^{+}$calcd for $\mathrm{C}_{9} \mathrm{H}_{10} \mathrm{~N}_{4} \mathrm{OS}$ : 254.33; found 255.0359 .

2-[(4-Methyl-4H-1,2,4-triazol-3-yl)thio]- $N$-(thiazol-2-yl) acetamide (2b)

Yield: $71 \%$. M.p. $212^{\circ} \mathrm{C}$.

${ }^{1} \mathrm{H}-\mathrm{NMR}\left(300 \mathrm{MHz}, \mathrm{DMSO}-\mathrm{d}_{6}, \mathrm{ppm}\right) \delta: 3.59\left(3 \mathrm{H}, \mathrm{s},-\mathrm{CH}_{3}\right)$, $4.14\left(2 \mathrm{H}, \mathrm{s},-\mathrm{CH}_{2}\right), 7.23(1 \mathrm{H}, \mathrm{d}, J=3.54 \mathrm{~Hz}, \mathrm{Ar}-\mathrm{H}), 7.48(1 \mathrm{H}$, d, $J=3.54 \mathrm{~Hz}, \mathrm{Ar}-\mathrm{H}), 8.56(1 \mathrm{H}, \mathrm{s}, \mathrm{Ar}-\mathrm{H}), 12.38(1 \mathrm{H}, \mathrm{s},-\mathrm{NH})$.

${ }^{13} \mathrm{C}-\mathrm{NMR}$ (75 MHz, DMSO-d , ppm) $\delta: ~ 31.28, ~ 36.61,114.24$, 138.23, 146.79, 148.83, 158.19, 166.59.

For $\mathrm{C}_{8} \mathrm{H}_{9} \mathrm{~N}_{5} \mathrm{OS}_{2}$ calculated: $37.64 \% \mathrm{C}, 3.55 \% \mathrm{H}, 27.43 \% \mathrm{~N}$, found: $37.58 \% \mathrm{C}, 3.59 \% \mathrm{H}, 27.48 \% \mathrm{~N}$.

HRMS (m/z): $[\mathrm{M}+\mathrm{H}]^{+}$calcd for $\mathrm{C}_{8} \mathrm{H}_{9} \mathrm{~N}_{5} \mathrm{OS}_{2}: 255.31$; found 256.0319 .

2-[(1-Methyl-1H-tetrazol-5-yl)thio]-N-(thiazol-2-yl) acetamide $(2 c)$

Yield: 73 \%. M.p. $225^{\circ} \mathrm{C}$.

${ }^{1} \mathrm{H}-\mathrm{NMR}\left(300 \mathrm{MHz}, \mathrm{DMSO}-\mathrm{d}_{6}\right.$, ppm) $\delta: 3.98\left(3 \mathrm{H}, \mathrm{s},-\mathrm{CH}_{3}\right)$, $4.36\left(2 \mathrm{H}, \mathrm{s},-\mathrm{CH}_{2}\right), 7.24(1 \mathrm{H}, \mathrm{d}, J=3.54 \mathrm{~Hz}, \mathrm{Ar}-\mathrm{H}), 7.49(1 \mathrm{H}$, d, $J=3.54 \mathrm{~Hz}$, Ar-H), 12.47 (1H, s, -NH).

${ }^{13} \mathrm{C}-\mathrm{NMR}$ (75 MHz, DMSO-d , ppm) $\delta: ~ 34.14, ~ 36.62, ~ 114.34$, $138.24,153.59,158.17,165.87$.

For $\mathrm{C}_{7} \mathrm{H}_{8} \mathrm{~N}_{6} \mathrm{OS}_{2}$ calculated: $32.80 \% \mathrm{C}, 3.15 \% \mathrm{H}, 32.79 \% \mathrm{~N}$, found: $32.88 \% \mathrm{C}, 3.17 \% \mathrm{H}, 32.82 \% \mathrm{~N}$.

HRMS (m/z): $[\mathrm{M}+\mathrm{H}]^{+}$calcd for $\mathrm{C}_{7} \mathrm{H}_{8} \mathrm{~N}_{6} \mathrm{OS}_{2}: 256.30$; found 257.0765

2-[(1-Methyl-1H-imidazol-2-yl)thio]- $N$-(4-phenylthiazol2-yl)acetamide (2d)

Yield: $69 \%$. M.p. $96^{\circ} \mathrm{C}$.

${ }^{1} \mathrm{H}-\mathrm{NMR}\left(300 \mathrm{MHz}, \mathrm{DMSO}-\mathrm{d}_{6}, \mathrm{ppm}\right) \delta: 3.60\left(3 \mathrm{H}, \mathrm{s},-\mathrm{CH}_{3}\right)$, 3.99 (2H, s, $\left.-\mathrm{CH}_{2}\right), 7.26-7.35(2 \mathrm{H}, \mathrm{m}, \mathrm{Ar}-\mathrm{H}), 7.39-7.45(3 \mathrm{H}$, m, Ar-H), 7.63 (1H, s, Ar-H), 7.89 (2H,d, J=7.17 Hz, Ar-H), $12.58(1 \mathrm{H}, \mathrm{s},-\mathrm{NH})$. 
${ }^{13} \mathrm{C}-\mathrm{NMR}$ (75 MHz, DMSO-d , ppm) $\delta: ~ 33.45,37.38,108.73$, $124.15,126.13,128.30,129.11,129.21,134.65,139.58,149.38$, $158.15,167.59$.

For $\mathrm{C}_{15} \mathrm{H}_{14} \mathrm{~N}_{4} \mathrm{OS}_{2}$ calculated: $54.53 \% \mathrm{C}, 4.27 \% \mathrm{H}, 16.96 \% \mathrm{~N}$, found: $54.57 \% \mathrm{C}, 4.29 \% \mathrm{H}, 16.92 \% \mathrm{~N}$.

HRMS (m/z): $[\mathrm{M}+\mathrm{H}]^{+}$calcd for $\mathrm{C}_{15} \mathrm{H}_{14} \mathrm{~N}_{4} \mathrm{OS}_{2}$ : 330.42; found 331.0668 .

2- [ (4-Methyl-4H-1,2,4-triazol-3-yl)thio]-N-(4phenylthiazol-2-yl)acetamide (2e) Yield: $67 \%$. M.p. $174^{\circ} \mathrm{C}$.

${ }^{1} \mathrm{H}-\mathrm{NMR}\left(300 \mathrm{MHz}, \mathrm{DMSO}-\mathrm{d}_{6}, \mathrm{ppm}\right) \delta: 3.60\left(3 \mathrm{H}, \mathrm{s},-\mathrm{CH}_{3}\right)$, $4.16\left(2 \mathrm{H}, \mathrm{s},-\mathrm{CH}_{2}\right), 7.32-7.46(3 \mathrm{H}, \mathrm{m}, \mathrm{Ar}-\mathrm{H}), 7.64(2 \mathrm{H}, \mathrm{d}$, $J=7.17 \mathrm{~Hz}, \mathrm{Ar}-\mathrm{H}), 8.56$ (1H, s, Ar-H), 12.54 (1H, s, -NH).

${ }^{13} \mathrm{C}-\mathrm{NMR}$ (75 MHz, DMSO-d , ppm) $\delta: ~ 31.28, ~ 36.65,108.78$, $126.13,128.32,129.22,134.64,146.82,149.41,158.11,166.93$.

For $\mathrm{C}_{14} \mathrm{H}_{13} \mathrm{~N}_{5} \mathrm{OS}_{2}$ calculated: $50.74 \% \mathrm{C}, 3.95 \% \mathrm{H}, 21.13 \% \mathrm{~N}$, found: $50.77 \% \mathrm{C}, 3.92 \% \mathrm{H}, 21.18 \% \mathrm{~N}$.

HRMS (m/z): $[\mathrm{M}+\mathrm{H}]^{+}$calcd for $\mathrm{C}_{14} \mathrm{H}_{13} \mathrm{~N}_{5} \mathrm{OS}_{2}: 331.41$; found 332.0628 .

2-[(1-Methyl-1H-tetrazol-5-yl)thio]-N-(4-phenylthiazol2-yl)acetamide (2f)

Yield: 70 \%. M.p. $193^{\circ} \mathrm{C}$.

${ }^{1} \mathrm{H}-\mathrm{NMR}\left(300 \mathrm{MHz}, \mathrm{DMSO}-\mathrm{d}_{6}, \mathrm{ppm}\right) \delta: 3.99\left(3 \mathrm{H}, \mathrm{s},-\mathrm{CH}_{3}\right)$, $4.39\left(2 \mathrm{H}, \mathrm{s},-\mathrm{CH}_{2}\right), 7.33-7.46(3 \mathrm{H}, \mathrm{m}, \mathrm{Ar}-\mathrm{H}), 7.65(1 \mathrm{H}, \mathrm{s}, \mathrm{Ar}-$ $\mathrm{H}), 7.90(2 \mathrm{H}, \mathrm{d}, J=7.14 \mathrm{~Hz}, \mathrm{Ar}-\mathrm{H}), 12.65$ (1H, s, -NH).

${ }^{13} \mathrm{C}-\mathrm{NMR}$ (75 MHz, DMSO-d , ppm) $\delta: 34.16,36.63,108.87$, $126.14,128.34,129.23,134.62,149.45,153.57,158.06,166.19$.
For $\mathrm{C}_{13} \mathrm{H}_{12} \mathrm{~N}_{6} \mathrm{OS}_{2}$ calculated: $46.97 \% \mathrm{C}, 3.64 \% \mathrm{H}, 25.28 \% \mathrm{~N}$, found: $50.01 \% \mathrm{C}, 3.67 \% \mathrm{H}, 22.32 \% \mathrm{~N}$.

HRMS (m/z): $[\mathrm{M}+\mathrm{H}]^{+}$calcd for $\mathrm{C}_{13} \mathrm{H}_{12} \mathrm{~N}_{6} \mathrm{OS}_{2}: 332.40$; found 333.0577 .

\section{Antimicrobial activity \\ Microorganisms and media}

12 bacteria, 4 yeasts, and 7 filamentous fungi were used as test organisms in this study.

Gram positive bacteria: Bacillus cereus ATCC 10876, Bacillus subtilis NRRL NRS-744, Enterococcus faecalis ATCC 51299, Listeria monocytogenes ATCC 19111 and Staphylococcus aureus ATCC 6538. Gram negative bacteria: Escherichia coli ATCC 25922, Enterobacter aerogenes NRRL B-3567, Klebsiella pneumoniae ATCC 700603, Pseudomonas aeruginosa ATCC 27853, Proteus vulgaris NRRL B-123, Salmonella typhimurium ATCC 14028, and Yersinia enterocolitica Y53 bacteria. Yeasts: Candida parapsilosis ATCC 22019, Candida albicans ATCC 90028, Candida glabrata ATCC 90030, and Candida krusei ATCC 6258. Filamentous fungi: Aspergillus niger ATCC 16404, Aspergillus flavus ATCC 9807, Aspergillus parasiticus NRRL 465, Aspe rgillus fumigatus NRRL 113, Penicillium expansum ATCC 24692, Penicillium citrinum ATCC 9849, Penicillium chryrsogenum ATCC 10106.

Bacteria and yeasts were kept on nutrient agar and yeast extract agar plates at $4{ }^{\circ} \mathrm{C}$, respectively. Fungal test cultures were subcultured on potato dextrose agar (PDA) for 5-7 d at $25^{\circ} \mathrm{C}$.

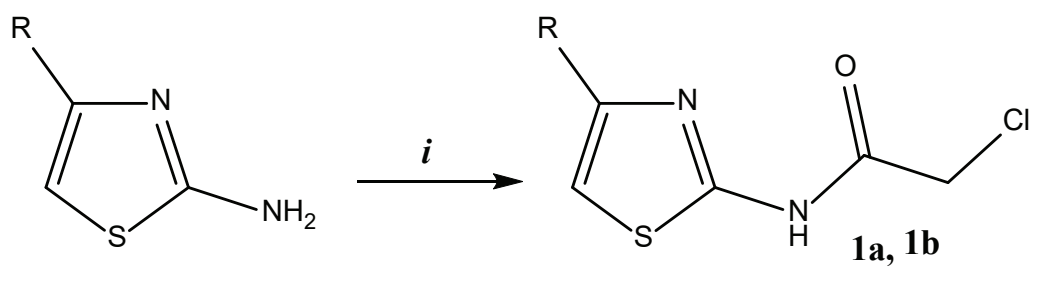

$\mathbf{R}=\mathrm{H}, \mathrm{Ph}$<smiles>[R]c1csc(NC(=O)CS[Al])n1</smiles>

Scheme 1. The synthesis protocol of the compounds. Reactants and conditions: $i: \mathrm{Et}_{3} \mathrm{~N}, \mathrm{ClCOCH}_{2} \mathrm{Cl}, \mathrm{THF}, 0^{\circ} \mathrm{C}$; ii: 2/3-Mercapto heterocyclics, $\mathrm{K}_{2} \mathrm{CO}_{3}$ 


\section{Determination of antimicrobial activity and Minimum Inhibitory Concentration (MIC) values of the substances}

Determination of antimicrobial activities and MIC values of the substances against to test microorganisms were used a serial dilution technique using 96-well microtitre plates, which has been described by the Clinical and Laboratory Standards Institute (14). For this aim, stock solutions of the substances were prepared in $20 \%$ dimethylsulfoxide (DMSO) and two fold dilution series from $4 \mathrm{mg} / \mathrm{mL}-7.8125$ $\mu \mathrm{g} / \mathrm{mL}$ were prepared using sterile distilled water. $100 \mu \mathrm{l}$ from each of the dilutions was added to 96-well microtiter plates. Bacterial and yeast cultures were standardized to $10^{8}$ $\mathrm{CFU} / \mathrm{mL}$ using $0.5 \mathrm{McF}$ arland standard solution. The fungal spore suspensions were prepared using sterile $0.1 \%$ Tween 80 and adjusted to about $10^{6}$ spores $/ \mathrm{mL} .100 \mu \mathrm{l}$ of each microorganism suspension was then added into the wells and incubated at $30-35^{\circ} \mathrm{C}$ for $24-48 \mathrm{~h}$ in aerobic conditions. The culture medium alone and medium containing bacteria without test compounds were considered as two controls. Triplicate wells were applied for each concentration of the individual test materials. Chloramphenicol and ketoconazole were used as standard antibacterial and antifungal agent, respectively. MIC values were detected by using MTT method (15-17). A concentration of $5 \mathrm{mg} / \mathrm{mL}$ MTT [3-(4, 5-dimethylthiazol-2-yl)-2, 5-diphenyltetrazolium bromide] was prepared in PBS (pH 7.2). $20 \mu \mathrm{l}$ of MTT solution was added to each single well and the 96 -well micro-titer plates were incubated for $3 \mathrm{~h}$ at $30-35^{\circ} \mathrm{C}$ to visually differentiate between the live and dead cells. A pink or red color in the microdilution well indicated bacterial growth; colorless wells were indicative of growth inhibition. The MIC was detected as the lowest substance concentration that completely inhibited microbial growth.

\section{RESULTS AND DISCUSSION}

\section{Chemisty}

Six new derivatives were synthesized with a simple, two-pot synthesis method as shown in Scheme 1. The structures of the compounds were confirmed by spectroscopic technics and elemental analysis results. In ${ }^{1} \mathrm{H}$ NMR spectra of the compounds, methyl protons were observed at 3.59-3.99 ppm whereas methylene protons were seen at about 3.97$4.39 \mathrm{ppm}$. The proton of nitrogen atom was detected at $12.38-12.65 \mathrm{ppm}$ and the other protons were seen at aromatic region and between 6.94-8.56 ppm as expected. In the ${ }^{13} \mathrm{C}$ NMR spectra of the compounds, methyl, methylene and carbonyl carbons were resonated at about 33.50, 37.50 and $167.30 \mathrm{ppm}$, respectively. The other carbon atoms were resonated at about 108.23-158.23 ppm. In the mass spectra of compounds, $[\mathrm{M}+1]$ peaks were determined in agreement with their molecular formula. Elemental analysis results were determined within the theorical values, $\pm 0.4 \%$.

\section{Antimicrobial activity}

All the synthesized compounds were screened for in vitro antimicrobial activity. The antimicrobial activity was evaluated against different bacterial, yeast and filamentous fungi strains. Results obtained in the present study relieved that all tested substances possess potential antimicrobial activity against all the test microorganisms. Results are summarized in Table 1. Among the bacteria Bacillus subtilis, Enterobacter aerogenes, and Staphylococcus aureus were the most resistant species to nearly all compound. In general evaluating, it was observed that all of the compounds had the activity in 0.25 and $1 \mathrm{mg} / \mathrm{mL}$ concentrations as MIC value. The lowest MIC values of the substances were found to be $0.125 \mathrm{mg} / \mathrm{mL}$ against only Yersinia enterocolitica with compounds $2 \mathrm{e}$ and $\mathbf{2 f}$. There was no direct correlation between the effectiveness of the substances to tested microorganisms. In addition, the antifungal activity of the compounds was examined against four Candida species. Compound $\mathbf{2} \mathbf{f}$ was found to be more effective against yeasts than the others with lower MIC values (Table 1). Otherwise, the MIC values obtained were similar for bacteria and yeast but higher for filamentous fungi. In antifungal activity evaluating for filamentous fungi, all the tested compounds inhibited the spore germination against tested fungi.

Among the synthesized compounds, 2a most active compound for Aspergillus parasiticus, 2b for Penicillum citrinum, 2c for Penicillum expansum, 2d for Penicillum citrinum and Penicillum cyrisogenum, 2e for Penicillum expansum, 2f for Penicillum expansum and Penicillum citrinum with $0.5 \mathrm{mg} / \mathrm{mL}$ MIC value when compared to others. According to these results, Penicillium species were more sensitive than Aspergillus species for the compounds. On the other hand, the compounds $2 \mathrm{e}$ and $\mathbf{2 f}$ (MIC 125 $\mu \mathrm{g} / \mathrm{mL}$ ) displayed half the potency of chloramphenicol to Yersinia enterocolitica. Other compounds had higher MIC values than standards. 
Table 1. Minimum inhibitory concentration (MIC) in $\mu \mathrm{g} / \mathrm{mL}$ of all substances and standard antibiotics in $\mu \mathrm{g} / \mathrm{mL}$ obtained using the microdilution method.

\begin{tabular}{|c|c|c|c|c|c|c|c|}
\hline Microorganisms & $2 a$ & $2 b$ & $2 \mathrm{c}$ & 2d & $2 e$ & $2 \mathrm{f}$ & Standards \\
\hline Bacteria & & & & & & & Chloramphenicol \\
\hline Bacillus cereus & 250 & 250 & 500 & 500 & 500 & 500 & 31.25 \\
\hline Bacillus subtilis & 500 & 1000 & 1000 & 1000 & 1000 & 1000 & 31.25 \\
\hline Escherichia coli & 250 & 250 & 250 & 500 & 500 & 500 & 62.5 \\
\hline Enterococcus faecalis & 250 & 250 & 250 & 500 & 500 & 500 & 62.5 \\
\hline Enterobacter aerogenes & 1000 & 500 & 1000 & 1000 & 1000 & 1000 & 31.25 \\
\hline Klebsiella pneumoniae & 500 & 250 & 500 & 500 & 1000 & 1000 & 62.5 \\
\hline Listeria monocytogenes & 250 & 250 & 250 & 500 & 500 & 500 & 125 \\
\hline Pseudomonas aeruginosa & 500 & 250 & 500 & 500 & 500 & 500 & 125 \\
\hline Proteus vulgaris & 500 & 250 & 500 & 500 & 500 & 500 & 125 \\
\hline Salmonella thyphimurium & 500 & 500 & 500 & 500 & 500 & 500 & 125 \\
\hline Staphylococcus aureus & 1000 & 1000 & 1000 & 1000 & 1000 & 500 & 125 \\
\hline Yersinia enterocolitica & 250 & 250 & 250 & 500 & 125 & 125 & 62.5 \\
\hline Yeasts & & & & & & & Ketoconazole \\
\hline Candida albicans & 500 & 500 & 500 & 1000 & 1000 & 250 & 62.5 \\
\hline Candida krusei & 500 & 500 & 500 & 1000 & 1000 & 250 & 62.5 \\
\hline Candida parapsilosis & 500 & 500 & 1000 & 1000 & 500 & 250 & 62.5 \\
\hline Candida glabrata & 500 & 1000 & 500 & 500 & 500 & 250 & 31.25 \\
\hline Filamentous fungi & & & & & & & Ketoconazole \\
\hline Aspergillus flavus & 1000 & 1000 & 1000 & 1000 & 1000 & 1000 & 31.25 \\
\hline Aspergillus parasiticus & 500 & 1000 & 1000 & 1000 & 1000 & 1000 & 125 \\
\hline Aspergillus niger & 1000 & 1000 & 1000 & 1000 & 1000 & 1000 & 62.5 \\
\hline Aspergillus fumigatus & 1000 & 1000 & 1000 & 1000 & 1000 & 1000 & 125 \\
\hline Penicillium expansum & 1000 & 1000 & 500 & 1000 & 500 & 500 & 125 \\
\hline Penicillium citrinum & 1000 & 500 & 1000 & 500 & 1000 & 500 & 125 \\
\hline Penicillium cyrisogenum & 1000 & 1000 & 1000 & 500 & 1000 & 1000 & 62.5 \\
\hline
\end{tabular}

\section{CONCLUSION}

In conclusion, the objective of the present study was to synthesize and evaluate the antimicrobial activities of some new thiazole compounds that could be used as potent antimicrobial drugs. Six different compounds were synthesized newly using 2 -aminothiazole derivatives as starting materials. It was observed that, the substances had bioactivity for the test bacteria in lower concentration than fungi. Although the MIC values obtained were higher than the standard antibiotics, it is an important result that the substances exhibited activity against for bacteria, yeast and filamentous fungi. Therefore all compounds were shown broad antimicrobial spectrum which have efficiency against pathogenic microorganisms associated with various human diseases. However, our results clearly revealed that especially compounds $\mathbf{2 e}$ and $\mathbf{2 f}$ exhibited good antimicrobial activity to Yersinia enterocolitica bacterium. Also, compound 2b exhibited half potency of standard with a MIC value of 125 $\mu \mathrm{g} / \mathrm{mL}$ against $P$ seudomonas aeruginosa and Proteus vulgaris. In addition, bacteria Listeria monocytogenes and Yersinia enterocolitica were found as the most susceptible species for the tested compounds.

New antimicrobial drug development has global emphasis and needs to be supported and established so the resistance of microorganisms to antibiotics is a situation that is constantly increasing. Because of this reason, we have performed the synthesis and investigation of potential, antimicrobial agents, in this study. 


\section{Yeni Tiyazol Türevlerinin Sentezi ve Antimikrobiyal Aktivitelerinin Araştırılması}

ÖZ

$\mathrm{Bu}$ çalışmada 2-[(1/4-metilimidazol/triazol/tetrazol-2/3/5-il) tiyo]-N-(4-sübstitüe tiyazol-2-il) asetamit türevleri (2a-f) sentezlenmiştir. Sentezlenen bu maddelerin bazı patojen Gram negatif, Gram pozitif bakteriler, Candida albicans, Candida glabrata, Candida krusei, ve Candida parapsilosis mayaları ile bazı Aspergillus ve Penicillium filamentöz fungus türlerine karşı antimikrobiyal aktiviteleri araştırılmıştır. Sentezlenen maddelerin test mikroorganizmalarının tümüne karşı önemli bir antimikrobiyal aktivitesi olduğu gözlenmiştir.

Anahtar kelimeler: antibakteriyel, antifungal, tiyazol

\section{REFERENCES}

1. Glotova TE, Dvorko MY, Albanov AI, Kazheva ON, Shilov GV, D'yachenko OA. 1,3-Dipolar cycloaddition of 3-phenylamino-5-phenylimino-1,2,4-dithiazole to 1-acyl-2phenylacetylenes-a new route to functionalized 1,3-thiazole derivatives. Russ J Org Chem 2008; 44: 1532-7.

2. Yadlapalli RK, Chourasia OP, Jogi MP, Podile AR, Perali RS. Design, synthesis and in vitro antimicrobial activity of novel phenylbenzamido-aminothiazole-based azasterol mimics. Med Chem Res 2013; 22: 2975-83.

3. Yurttaş L, Özkay Y, Karaca Gençer H, Acar U. Synthesis of some new thiazole derivatives and their biological activity evaluation. J Chem, 2015; 2015: 1-7.

4. Geronikaki A, Sotiropoulou E, Kourounakis P. Synthesis of some thiazole derivatives with prospective local anaesthetic activity. Pharmazie 1989; 44: 349.

5. Geronikaki A, Theophilidis G. Synthesis of 2-(aminoacetylamino)thiazole derivatives and comparison of their local anaesthetic activity by the method of action potential. Euro J Med Chem 1992; 27: 709-16.

6. Xiaoyun L, Xiaobo L, Baojie W, Scott GF, Lili C, Changlin Z, Qidong Y. Synthesis and evaluation of anti-tubercular and antibacterial activities of new 4-(2,6-dichlorobenzyloxy) phenyl thiazole, oxazole and imidazole derivatives. Part 2. Eur J Med Chem 2012; 49: 164-71.

7. Ulusoy N, Küçükbasmacı Ö. Synthesis and antimicrobial activity evaluation of new 1,2,4- triazoles and 1,3,4-thiadiazoles bearing imidazo[2,1-b]thiazole moiety. Eur J Med Chem 2010; 45: 63-8.

8. Ghorab MM, El-Batal AL. Synthesis of some new thiazole derivatives. antifungal activity and ultrastructure changes of some mycotoxin producing fungi. Boll Chim Farm 2002; 141: 110-7.
9. Çapan G, Ulusoy N, Ergenç N, Kiraz M. New 6-phenylimidazo[2,1-b]thiazole derivatives: Synthesis and antifungal activity. Monatsh Chem 1999; 130: 1399-1407.

10. Kumar A, Lata S, Saxena KK, Chandra T. Synthesis and evaluation of new substituted indolyl pyrazolines as antiinflammatory and analgesic activities. Indian Drugs 2009; $46: 43-8$.

11. Park JH, El-Gamal MI, Lee YS, Oh CH. New imidazo[2,1-b] thiazole derivatives: Synthesis, in vitro anticancer evaluation, and in silico studies. Eur J Med Chem 2011; 46: 5769-77.

12. Andreani A, Granaiola M, Guardigli M, Leoni A, Locatelli A, Morigi R, Rambaldi M, Roda A. Synthesis and chemiluminescent high throughput screening for inhibition of acetylcholinesterase activity by imidazo[2,1-b]thiazole derivatives. Eur J Med Chem 2005; 40: 1331-4.

13. Yurttas L, Şahin Z, Akalın Çiftçi G, Temel HE, Demirayak Ş. Synthesis of novel 3,5,6-trisubstituted triazine derivatives and their biological activity evaluation as potential antitumor and anti-inflammatory agents. Acta Pharm Sci 2016; 54: 83-92.

14. Clinical and Laboratory Standards Institute, CLSI. Performance standards for antimicrobial susceptibility testing, 18th informational supplement. CLSI document M100-S18. Wayne, PA: 2008.

15. Mosmann T. Rapid colorimetric assay for cellular growth and survival: Application to proliferation and cytotoxicity assays. J Immunol Meth 1983; 65: 55-63.

16. Marshall NJ, Goodwin CJ, Holt SJ. A critical assessment of the use of microculture tetrazolium assays to measure cell growth and function. Growth Regul 1995; 5: 69-84.

17. Raut U, Narang P, Mendiratta DK, Narang R, Deotale V. Evaluation of rapid MTT tube method for detection of drug susceptibility of Mycobacterium tuberculosis to rifampicin and isoniazid. Indian J Med Microbiol 2008; 26: 222-7. 